Elżbieta Dąbrowicz

Instytut Filologii Polskiej, Uniwersytet w Białymstoku

\title{
Biografia pochwalna z 9 maja 1801 roku. Lektura kontekstowa
}

W historii polskiej biografistyki xıx-wiecznej, którą warto by napisać, znajdzie się z pewnością miejsce dla jej odmiany pochwalnej, związanej z istnieniem warszawskiego Towarzystwa Przyjaciół Nauk, a także towarzystw $\mathrm{z}$ innych dzielnic porozbiorowych ${ }^{1}$. W XIX wieku wypowiadano na temat pochwał sprzeczne opinie, ale to raczej przysparza, niźli ujmuje im znaczenia. Skoro prowokowały dyskusję, widać dotykały spraw dla życia zbiorowego istotnych. Niejednoznaczność ocen wynikała też z zamętu co do ich klasyfikacji genologicznej. Jedni sytuowali pochwały w kręgu biografistyki, inni moralistyki, jeszcze inni - tekstów krytycznoliterackich...

Ton prześmiewczy wobec nich poddał Adam Mickiewicz jako autor pamfletu $O$ krytykach i recenzentach warszawskich z 1829

1 Towarzystwo Naukowe Krakowskie, założone w 1815 roku, w latach 1817-1872 wydawało „Rocznik Towarzystwa Naukowego Krakowskiego z Uniwersytetem Krakowskim Połączonego” (dalej: „Roczniki”). Pierwsza pochwała została zamieszczona w tomie trzecim (1818) - Pochwata Józefa Czerwiakowskiego. Towarzystwo Przyjaciół Nauk w Poznaniu, działające od 1857 roku, również miało swoje „Roczniki” z działem nekrologów. 
roku². Pochwały włączył poeta do repertuaru wypowiedzi poprzez które „krytycy i recenzenci” pełnili funkcję opiniotwórców w dziedzinie literatury:

W takim stanie krytyki [obnażał bezlitośnie ich poczynania - E.D.] godne uwagi i budujące jest dobre porozumienie sąsiedzkie, w jakiem krytycy z sobą i z autorami żyli, uszanowanie, z jakiem zobopolne wyroki przyjmowali i skrupulatność, z jaką je dosłownie z ust do ust, z pióra do pióra przelewali. Zdanie księdza Golańskiego przytacza Franciszek Dmochowski, Franciszka Dmochowskiego przytacza Ludwik Osiński, wszystkich przytacza Stanisław Potocki, wszyscy przytaczają Stanisława Potockiego. Zdania te koncentrują się na chwilę w historii literatury Bentkowskiego, skąd w różnych przytaczaniach kanałem dzienników, przedmów i mów pochwalnych do swoich źródeł wracają. Utrzymuje się tym sposobem w Warszawie w ciągłym obiegu pewna liczba zdań, niemających gdzieindziej żadnej wartości, jak na Żmudzi ciągle krążą stare talary holenderskie i orty. [Dmochowski 1829: 51-56 $]^{3}$

Mickiewicz posłużył się tonem kpiarskim, sama sprawa była jednak nader poważna: we własnym mniemaniu uderzył w zamkniętą i tamującą twórcze przepływy, uzurpowaną elitarność warszawskiej krytyki. Atak powiódł się nadzwyczajnie. Pisząc o zdaniach, które poza kółkiem znajomych nie mają ,żadnej wartości”, poeta na długo utrwalił pogląd o laudacyjnym pustosłowiu, którego nie sposób traktować serio.

Do czytelnika o krytykach i recenzentach warszawskich opublikował Mickiewicz jako wstęp do pierwszego tomu Poezji wydanego w Petersburgu (1829), zawierającego m.in. Konrada Wallenroda, przyjętego z oburzeniem w elitarnych kręgach Warszawy. W cytatach z druków XIX-wiecznych modernizuję ortografię oraz interpunkcję.

3 Sensacyjny wstęp Mickiewicza w tym samym roku przedrukował w Warszawie Franciszek Salezy Dmochowski razem ze swoją odpowiedzią. W wydaniu tym cytowany w artykule fragment ma nieco inną postać niż w pierwodruku; opuszczono w nim jedno z ogniw w opiniotwórczym środowisku warszawskim. Franciszek Salezy przeoczył bądź też celowo wyeliminował nazwisko Ludwika Osińskiego [Dmochowski 1829: 54]. 
Warszawskim opiniotwórcom wyjątkowo uporczywie wypominano jedno z takich zdań bez pokrycia. Chodzi o ustęp z Pochwaty Józefa Szymanowskiego. Kilkanaście lat po Mickiewiczowskim pamflecie Kazimierz Władysław Wójcicki [1845: 340] w Historii literatury polskiej $w$ zarysach przywoływał wspomnianą pochwałę jako kuriozum dobrze wszystkim znane: „Stanisław Potocki, mały poemat z prozy Montesquieu'go przerobiony, nazwał arcydziełem, co dało powód późniejszym, do szydzenia i z autora i krytyka”. Uwadze powyższej towarzyszył cytat z „przesadzonej pochwały”, gdzie przetłumaczenie Świątyni Wenery $\mathrm{z}$ Knidos zostało uznane za przełomowe wydarzenie $\mathrm{w}$ dziejach literatury polskiej. Wójcickiemu nie tylko zależało na tym, by podtrzymywać negatywną opinię o kompetencjach krytycznych Stanisława Kostki Potockiego, lecz także stawiał przed sobą cel o szerszym zasięgu. Potocki uosabiał tu całe Towarzystwo Przyjaciół Nauk, które po szumnych deklaracjach napoczęło rozmaite pożyteczne inicjatywy, ale ich nie doprowadziło do końca, przez co nadużyło społecznego zaufania. Wójcicki [1845: 353] nie szczędził „powagom” kąśliwych określeń; zarzucał im „niedołężność”, „słabość”, „ospałość”. Nie tamował gniewu na rozleniwioną „arystokrację naukową", która mimo obfitych środków i sprzyjających warunków prawie nic wartościowego po sobie nie zostawiła. Obiecywano bez porównania więcej, niż zdołano przywieść do skutku. Wrażenie niewspółmierności między opinią a stanem faktycznym wzmagała lektura pochwał, stanowiących ważną część dorobku publikacyjnego zawartego w „Rocznikach”. Fragment Pochwały Józefa Szymanowskiego z uniesieniami nad Świątynia Wenery $z$ Knidos stanowił koronny argument w antyarystokratycznej filipice. „Niedołężni” arystokraci kadzidlanym dymem pochwał zakrywali mizerię swoich rzeczywistych dokonań.

Ośmieszając pochwalną retorykę Potockiego, Wójcicki zdawał się nie przyjmować do wiadomości, że podstawową regułą tego rodzaju przemowy jest amplifikacja, a jeden z obiegowych toposów polega na pomniejszeniu przeszłości na rzecz teraźniejszości [zob. Dziechcińska 1970: 70-72, 1971; Curtius 1997: 173-174] $]^{4}$. Nie 
wydaje się jednak, by jego ocena wystąpienia Potockiego wynikała z nieznajomość zasad retoryki. Wójcickiemu chodziło raczej o to, by dając wyraz zdegustowaniu „przesadą”, zaznaczyć swój zewnętrzny wobec Towarzystwa punkt widzenia, okazać, że nie należy do tego samego co Potocki środowiska, a w związku z tym nie poczuwa się do żadnej z nim solidarności. Uporczywie podkreślał arystokratyzm stowarzyszonych, upatrując w nim przyczyny niskiej efektywności działań szacownego gremium. Najwidoczniej uważał, że członkowie Towarzystwa tylko pozowali na uczonych, sycąc tym swoją arystokratyczną próżność. Sztucznie podtrzymywali uprzywilejowaną pozycję w społeczeństwie, która w następstwie rewolucyjnych zmian w Europie, uległa zakwestionowaniu. Pochwała TPN-owska raziła więc anachronizmem. Nie było już świata, w którym obowiązywał taki rodzaj pośmiertnego oddawania czcis $^{5}$. Wójcicki, pisząc o Towarzystwie, starał się trzymać jak najdalej od tonu pochwalnego. Użył jego przykładu ku przestrodze „dla każdej arystokracji naukowej, co myśli postępu nie pojmuje albo pragnie zdeptać” [Wójcicki 1845: 355].

Inaczej zapatrywał się na „przyjaciół nauk” Franciszek Salezy Dmochowski we wspomnieniach opublikowanych w 1858 roku. Korzystając z łagodniejszego po wojnie krymskiej klimatu politycznego, chciał zrewidować utarty pogląd na relacje między klasykami i romantykami oraz własny udział w tzw. walce między nimi. Współcześnie ze wspomnieniami Dmochowskiego ukazało się ośmiotomowe wydanie Pism Mickiewicza, którego twórczość skazano na wygnanie z zaboru rosyjskiego w 1834 roku. Autor wspomnień starał się dawny konflikt ex post zażegnać, podkreślając, że pokolenie romantyków w gruncie rzeczy wiele zawdzięczało swoim poprzednikom:

Z dzieł poznajemy działaczów - stare to aksjoma jakże silnie przemawia za stroną literatów z pierwszych lat dziewiętnastego wieku! Ich usiłowania, przykłady, zachęty prędko

5 Wójcicki odmawiał uczestnictwa w „fabrykacji” autorytetu Towarzystwa. Nawiązuję do tytułu książki Petera Burke’a [2011], poświęconej tworzeniu wizerunku (gloryfikacji) króla, zależności między splendorem, przepychem a władzą. 
ukształciły młodsze pokolenie, które zrównało lub prześcignęło nauczycieli swoich. [Dmochowski 1959: 223]

W przeciwieństwie do Wójcickiego, który uważal, że arystokratyczni członkowie towarzystwa nadużyli instytucjonalnego rytuału, żeby ratować swój upadający prestiż, Dmochowski traktował ich jako autentyczną elitę narodową, wywierającą realny i pozytywny wpływ na kolejną generację, nie wyłączając romantyków. Za wartościową część ich dorobku uważał przemowy pochwalne:

Niejeden z teraźniejszych przyganiaczy z szyderstwem wspomina owe pochwały, którymi publicznie czczono pamięć zmarłych pisarzy, i twierdzi, że cel Towarzystwa ograniczał się na wzajemnym chwaleniu. Myli się, kto na te pochwały $\mathrm{z}$ tak niskiego stanowiska poogląda. [Dmochowski 1959: 223]

Ocena „z niskiego stanowiska”, ograniczona do samej literatury, nie uwzględniała „zasług w obywatelskim zawodzie” stowarzyszonych ani też samej doniosłości obrad publicznych. Dla Dmochowskiego było oczywiste, że akt publicznego wyrażania szacunku wymaga specjalnej formy, podniesionego tonu. Nie da się też przecenić pożytków takich aktów dla pedagogiki społecznej i międzypokoleniowej transmisji kultury. Dmochowski podkreślał również rolę Towarzystwa w przygotowaniu kadr dla uniwersytetu w Warszawie.

Towarzystwo Naukowe Warszawskie w roku 1860 przypomniał Fryderyk Skarbek, ubolewając nad jego efemerycznością. On również bronił pochwał przed nazbyt surową krytyką. „Nader ważnym materiałem do biografii polskiej są pochwały i życiorysy członków Towarzystwa i znakomitych Polaków, których jest przeszło pięćdziesiąt [...]” [Skarbek 1860: 123]. Zarysował jeszcze inny od Wójcickiego i Dmochowskiego pryzmat, przez który należałoby oglądać twórczość pochwalną, a mianowicie przez odniesienie do „biografii polskiej”. W tej perspektywie pochwały i „życiorysy” - bo w „Rocznikach” i te publikowano - stanowily materiał wzbogacający biograficzne zasoby o różnym - jak można sądzić - kształcie gatunkowym. 
Pochwał trudno było ówcześnie bronić nie tylko dlatego, że nie cenili ich romantycy, ale też dlatego, że na ogół krytycznie odnoszono się do twórczości biograficzno-retorycznej pochodzącej z epok wcześniejszych. Łatwo można sobie wyobrazić myślowy przeskok od pochwał TPN-owskich do rozpasanego - jak to zwykle opisywano - w XVII wieku „panegiryzmu” i ,jezuityzmu”. Ale i w cenionym wieku XVI nie dostrzegano wzorów, do których można by się odwołać.

Pisarstwu biograficznemu, zarówno w jego odmianie historiograficznej, jak i pochwalnej, przyglądał się m.in. Wacław Aleksander Maciejowski w swojej syntezie Piśmiennictwo polskie od czasów najdawniejszych aż do roku 1830 . O każdym z rodzajów pisał osobno, nie naruszając granicy między historiografią a wymową. Na potrzeby niniejszych rozważań nie zaszkodzi połączyć te uwagi.

Pisząc o rodzimej biografistyce historycznej autor Piśmiennictwa... wskazywał - nie mogło być inaczej - na tradycje grecko-rzymskie. Dowodził, że w Xvi i XvII wieku czytano w Polsce dzieła Plutarcha, Salustiusza i Tacyta. Z uznaniem pisał o historykach, którzy

wyszukiwali w przeszłości i teraźniejszości postacie wielkie i małe, czyli wielką duszą ciała śmiertelnych ożywione stawiali na jaw, a około nich mniejsze lub wcale niepozorne figury narodów, mężów, niewiast (Zenobii, Palmiry) grupując, z szczególną zręcznością wypadki dziejów w harmonijną całość wiązali z niemi, w celach i dążnościach osób głównych i podrzędnych historią świata całego z wielką przedstawiając zręcznością. [Maciejowski 1852: 700-701]

Maciejowski zaznaczył, że w Polsce przeważył wpływ Plutarcha, ale on sam wyżej cenił rzymską historiografię z techniką "grupowania” wydarzeń historycznych w „życiorysach”:

Tak Salustiusz w pamiętnikach swych, o wojnach z powodu Katyliny i Jugurty przez Rzymian we Włoszech i Afryce prowadzonych, przedstawiając w upadku moralności słabość rządu, i wpływ nań pospólstwa wykazując, ugrupował Rzym 
i ówczesnego świata dzieje w życiorysach Katona, Juliusza Cezara, Mariusza. Tak i Tacyt smutny stan państwa pod srogiemi Domicjana rządami wyjawiając, zjednoczył wszystko około Agrykoli, małego ciałem, wielkiego duszą męża; w którego życiorysie przedstawiwszy spółczesne dzieje, dał naukę dla tych, co zuchwalstwo wielbić zwykli i (że tu powtórzę jego słowa) przekonał nas o tem, „że i pod złymi pany można być zacnym obywatelem [...]”. [Maciejowski 1852: 701]

Wedle przypuszczenia Maciejowskiego [1852: 701] o popularności u nas Plutarcha zadecydowało to, że „okwicie sadząc zdaniami, zdał się więcej przydatny do rozumów polskich, dziwnie sobie w używaniu przysłów podobających". Notując spostrzeżenia co do wymowy pochwalnej (panegirycznej), badacz zauważał, że pierwsze próby w tym gatunku poczynili cudzoziemcy. Przemowy układane przez Polaków miały charakter naśladowczy, fabrykowano je też z czasem bez umiaru. Wbrew Kazimierzowi Brodzińskiemu, który twierdzil, że dawni Polacy najbardziej rozwinęli swoje talenty w wymowie, zdaniem Maciejowskiego szlachta celowała jedynie w gawędzie, nie radziła sobie jednak z oratorstwem uczonym. Zestawiając uwagi autora Piśmiennictwa... o biografistyce historiograficznej i pochwalnej, daje się zauważyć jej wspólny rys: brak równowagi między wiarygodną faktografią a retoryczną ornamentyką. Sądząc z omówionych wniosków, biografowie polscy w XIX wieku nie mieli rodzimej tradycji, która by im dostarczała wzorów rzetelności naukowej.

O pochwałach pisał obszernie Karol Mecherzyński w Historii wymowy w Polsce. Książka obejmowała okres do połowy XVIII wieku. Nazywając wiek XVII „wiekiem panegiryków” [Mecherzyński 1860: 340], autor podążał za opiniami, które obowiązywały w polskim piśmiennictwie od wystąpień Stanisława Konarskiego.

Panegiryki są wyrazem najwyższego zepsucia i upodlenia u nas wymowy - w nich najwydatniej odbiło się ówczesne obyczajów zepsucie. Podobny był los wymowy rzymskiej po upadku Rzeczypospolitej, gdy zmiana stosunków politycznych, a z nią zmiana obyczajów i smaku, szkodliwy nań wpływ 
wywarly. W szkołach krasomówców nabrawszy retorycznego ducha, i sprzymierzywszy się z pochlebstwem, uniżonością, wybujała w czczą deklamacją. [Mecherzyński 1860: 344-345] ${ }^{6}$

Epitet „czczy” towarzyszył również ocenom pochwał TPN-owskich.

Negatywne opinie o biografiach pochwalnych „przyjaciół nauk" wyplywały nie tyle z ich systematycznej analizy, ile z zawiedzionych oczekiwań późniejszych czytelników, którzy przykładali do nich kryteria wedle własnych potrzeb. Nie darmo zresztą pozytywnie usposobiony do TPN-u Dmochowski podkreślał, że bohaterów pochwał miał szczęście widywać, uczestniczył w ich pogrzebach. Podkreślał różnicę perspektywy uczestnika i świadka oraz kogoś takiego jak Mickiewicz, kto „krytyków i recenzentów” znał jedynie z tekstów, a prawdę powiedziawszy, głównie z bałamutnych pogłosek.

Do zawiedzionych należał Julian Bartoszewicz. Różnił się jednak od Mickiewicza i Wójcickiego, gdyż doceniał wagę samego rytuału pośmiertnego szacowania zasług. „Tak więc żadna praca, żadne zasługi nie ginęły darmo".Jego rozczarowanie wynikało stąd, że nie znajdował w pochwałach materiałów przydatnych w realizacji jego własnych zamierzeń naukowych jako historyka literatury. Przy okazji jednak wydobył ważną cechę gatunkową pochwały TPN-owskiej:

$\mathrm{Z}$ takiej instytucji wiele $\mathrm{w}$ istocie mogłyby zyskać $\mathrm{z}$ czasem dzieje literatury; w mowach tych leżałby niezmiernie ważny, a z pierwszej ręki czerpany materiał, to jest zeznania spółczesnych o spółczesnych, ale brak ówczesnej krytyki wykrzywił piękną instytucję i zamienił ją w czczą formę. Nikt wówczas jeszcze nie pojmował jak można pisać prawdę o znajomych, o przyjaciołach. [Bartoszewicz 1877: 141]

6 Trzeba jednak dodać, że historyk wymowy nie ograniczył się do samego tylko podtrzymywania dawno rzuconej anatemy na literaturę wieku XvII, lecz starał się czarny obraz zniuansować. 
Pochwały TPN-owskie stanowiły zatem „zeznania spółczesnych o spółczesnych”, lecz wedle oceny Bartoszewicza były wadliwie sporządzone, brakowało bowiem kulturowych wzorów, jak formę taką uprawiać. Definicję powyższą - mimo że opisuje tylko możliwość, nie zaś spełnienie - warto zapamiętać. Niewykluczone zresztą, że przynajmniej niektóre z pochwał zbliżały się do jej realizacji (zob. Pochwała Ignacego Krasickiego pióra Franciszka Ksawerego Dmochowskiego).

W najnowszej obszernej publikacji poświęconej Towarzystwu Przyjaciół Nauk - w Pamięci sentymentalnej. Praktykach pamięci w kręgu Towarzystwa Warszawskiego Przyjaciół Nauk Hanny Jurkowskiej - dawne jego kłopoty z reputacją zajmują miejsca niewiele. Zdecydowany przełom w opiniach na temat wartości spuścizny TPN dokonał się bowiem już dawno, głównie za sprawą monumentalnej „kroniki” Aleksandra Kraushara. On sam natomiast cytował aprobatywnie Stanisława Tarnowskiego, który nieco wcześniej w wyważony sposób opowiedział się za Towarzystwem w swojej Historii literatury polskiej. Tarnowski pokazal, jak pisać o Towarzystwie, nie popadając w osławioną „przesadę”. W odróżnieniu od „szyderców”, którzy zarzucali „przyjaciołom nauk” lenistwo i marnotrawstwo, uczony hrabia podkreślał ich „wysoki zmysł organizacyjny i praktyczny” [Kraushar 1900: 11]. Nie oddzielał prac towarzystwa od działalności państwowej w ostatniej fazie istnienia Rzeczypospolitej, za Księstwa Warszawskiego i Królestwa Polskiego. Towarzystwo stanowiło jedno z pól w ich aktywnym życiu, przypadającym na jakże burzliwe czasy.

Autorka Pamięci sentymentalnej... nieco tłumi aktywistyczny impet, który docenił Tarnowski, łącząc polityczne i literackie aspekty działalności członków Towarzystwa Przyjaciół Nauk, ich wyczulenie na zmienność światowych koniunktur. Samo uprzywilejowanie problematyki pamięci w książce z 2014 roku musiało przynieść taki efekt oddalenia od polityki. Niekiedy wprawdzie badaczka koncentruje się na konkretnych posiedzeniach, ale ponieważ za obiekt swojego namysłu obiera "praktyki pamięci”, nacechowane - jak stwierdza - „pewną widoczną z zewnątrz powtarzalnością czy regularnością” [Jurkowska 2014: 12], siłą rzeczy musi eksponować długofalowość „praktyk” kosztem dra- 
matyzmu konkretnych poszczególnych sytuacji. Preferencję tę widać wyraźnie, kiedy omawia pochwały; poświęca im osobny podrozdział („Dla zachęcenia żyjacych - pamięć zmartych członków potomności podawać”). Zastanawia się nad aspektem rytualnym przemów pośmiertnych, powielanym z okazji na okazję „scenariuszem”, próbując zrekonstruować lansowany przez Towarzystwo „wzór osobowy” [Jurkowska 2014: 80-87]. Żadnej z pochwał nie przygląda się z bliska, niwelując tym samym ich wymiar zdarzeniowy. A przecież spośród dat, które przywołuje się w pochwałach, najważniejsza bodaj jest data wygłoszenia, stanowiąca zresztą nieodzowny element tytułu. Pochwała, mimo że silnie sformalizowana, stanowi bądź co bądź reakcję na śmierć konkretnego człowieka, akt upamiętnienia ma zaś prócz strony rytualnej wymiar jednorazowego zdarzenia. Opublikowana przemowa nie stanowi ekwiwalentu wygłoszonej/, odczytanej”. Nawet jeśli tekst obu jest tożsamy co do joty. Pochwała jest częścią publicznego posiedzenia Towarzystwa, złożonego z innych jeszcze elementów, posiedzenia, które się wydarza jednorazowo z udziałem konkretnej, współobecnej publiczności. Lektura pochwały opublikowanej w „Rocznikach” może być ponawiana czy przerywana w dowolnym momencie, a jej rozproszonych czytelników - prócz znajomości języka - nic ze sobą nie musi łączyć.

Potraktuję pochwały jako wypowiedzi z datą i skupię uwagę na jednej spośród nich, wygłoszonej 9 maja 1801 roku, zawartej w inicjalnym tomie „Roczników” z roku 1802. Chodzi o złej sławy Pochwałe Józefa Szymanowskiego, której wysłuchano podczas drugiego z kolei publicznego zebrania Towarzystwa w dniu 9 maja 1801 roku. Była to pierwsza pochwała, jaką w gronie tym zaprezentowano. Dzięki temu pierwszeństwu służyła kolejnym mówcom-biografom za punkt odniesienia, chociaż sam laudator nieco osłabił jej rangę wyjaśnieniem, że pochwałę miał wygłosić kto inny, on zaś przemówił jedynie w zastępstwie. Z mojego punktu widzenia zasygnalizowana wstępnie prowizoryczność („tymczasowość”) wystąpienia Potockiego nie tylko nie przemawia na jego niekorzyść, ale wręcz podkreśla dramat chwili - niepewny status Towarzystwa i destabilizację całego nieomal ówczesnego świata. Założone w 1800 roku w Warszawie pod władzą pruską i za jej przyzwole- 
niem, ale niepotwierdzonym urzędową „sankcją” w pierwszym okresie istnienia, Towarzystwo oficjalnie obradowało rzadko między pierwszym publicznym spotkaniem ( 23 listopada 1800 roku) a następnym, wspomnianym majowym, upłynęło prawie pół roku. W gorącym tym półroczu carobójstwo popełnione w Rosji na Pawle I otworzyło drogę do tronu Aleksandrowi I, we Francji próbowano zabić Napoleona Bonaparte, pierwszego konsula, co w efekcie jednak wzmocniło jego pozycję. Francja i Austria zawarły pokój w Lunéville, ale nikt pewnie nie wierzył w jego trwałość, w Egipcie wciąż pasowały się ze sobą wojska angielskie i francuskie. Ówczesne gazety obfitowały w doniesienia o ruchach wojsk i dyplomatycznych podchodach, informacje sprawdzone mieszały się z pogłoskami. Rozległy zasięg działań wojennych i dostępność prasy sprawiły, że nigdy przedtem tak wielka liczba ludzi nie obserwowała przemian w świecie, przemian dotykających wszystkich dziedzin życia, łącznie z tymi, które dotąd uchodziły za wyjątkowo stabilne. W numerze „Gazety Warszawskiej” z 12 maja 1801 roku informowano np. o nowych przepisach we Francji dotyczących grzebania umarłych:

Instytucje pogrzebowe są jedną z najpierwszych zasad cywilizacji. Po wyprowadzeniu ze zwyczaju przez rewolucją obrządków pogrzebowych, w których dla bogaczów nadto było przepychu, a dla ubóstwa nadto upodlenia nędzy; dzisiejsze porównały wprawdzie bogacza z ubogim, lecz gdy i publiczna opinia i moralność ganią obnażenie w teraźniejszych pogrzebach, godną jest rzeczą pierwszego miasta Rzplitej, przykładem swoim oznaczyć przystojność pogrzebów, a nade wszystko poświęcić, jako pobożny obowiązek gminu, staranie o pogrzebie ubogich. [„Gazeta Warszawska” 1801: 665]

Nawet odwieczny rytuał pogrzebowy nie uniknął przeobrażeń.

Niepewny status Towarzystwa miał źródło nie tylko w niespokojnej sytuacji międzynarodowej. Trudno było uzasadnić jego misję w sposób niebudzący niepokoju władz pruskich. Idea Towarzystwa, jak wiadomo, nie była zamysłem bez precedensu; w Wieku Świateł inicjatywy o podobnym charakterze wynikały 
z ducha czasu7. Należy jednak dodać, że punkt odniesienia dla warszawskiego Towarzystwa stanowiła przede wszystkim Akademia Francuska (założona w 1653 roku przez kardynała Richelieu), której misja w punkcie wyjścia miała polegać na ustaleniu zasad języka francuskiego. Na popatrywanie polskich „przyjaciół nauk” w kierunku tradycji francuskich wskazuje wysoka pozycja języka jako obiektu deklaracji programowych oraz inicjowanych przedsięwzięć, a także nastawienie normatywistyczne. W pierwszej odezwie z 1802 roku czytamy o celach Towarzystwa: „utrzymywać język polski w swej czystości” [Albertandi 1802: V]. Mimo podobieństwa celów do tych stawianych w Akademii Francuskiej nie da się jednak traktować polskiej instytucji jako odpowiednika nadsekwańskiej. Akademia Francuska czuwała nad językiem francuskim jako językiem obowiązującym w całym państwie i sprzyjającym jego integracji. Język pozostający pod opieką państwowej Akademii dominował nad wszelkimi językami regionalnymi. Towarzystwo Przyjaciół Nauk natomiast zobowiązywało się do czuwania nad językiem polskim, który w Prusach Południowych nie obowiązywał jako język urzędowy. Nie mogło więc mieć Towarzystwo na celu spójności państwa, w ramach którego funkcjonowało. Konsekwencją jego działalności musiała być kulturowa autonomizacja świeżych nabytków terytorialnych Prus. Nic też dziwnego, że do samego końca okresu pruskiego nie udało się uzyskać mocnej podstawy prawnej dla istnienia Towarzystwa. Król pruski wzią je pod swoją opiekę, ale akt ten nie był na tyle wiążący, by Towarzystwo mogło nabyć bez biurokratycznych wstrętów stałą siedzibę. Niewątpliwie zostało zalegalizowane tylko dzięki temu, że francuskie sukcesy militarne z jednej strony, z drugiej zaś korzystne dla Polaków zmiany w podejściu władz rosyjskich po śmierci Katarzyny II, a niedługo później Pawła I, wpłynęły na złagodzenie polityki Prus wobec polskich poddanych.

Model Akademii Francuskiej nie tylko nie przystawał do warunków, w jakich musiało działać Towarzystwo warszawskie,

7 W związku z TPN pisze się na ogół o towarzystwach naukowych na ziemiach polskich [zob. Smoleński 1949 (rozdz. Towarzystwa naukowe i literackie w Polsce wieku XVIII); Jurkowska 2014: 53-64]. 
lecz także $\mathrm{z}$ innego jeszcze powodu trudny był do oficjalnego emulowania. W samej Francji przecież nic już nie przypominało czasów kardynała Richelieu. Rewolucja Francuska zdruzgotała wszystkie instytucie ancien régime łącznie z Akademią. Na łamach "Nowego Pamiętnika Warszawskiego" z 1801 roku, redagowanego przez Franciszka Ksawerego Dmochowskiego ${ }^{8}$, udostępniano w odcinkach Nowy Paryż autorstwa Louisa-Sébastiena Merciera9. W opisywanym tu rewolucyjnym Paryżu szaleje terror, giną ludzie, których zdawał się otaczać powszechny szacunek, cześć oddaje się zbrodniarzom, wandalizm nie oszczędza żadnych świętości. Kiedy w Warszawie organizuje się Towarzystwo, Akademia Francuska jako instytucja nie istnieje. Pierwszy prezes „przyjaciól nauk”, Jan Chrzciciel Albertrandi, biskup zenopolitański, w przemowie z 18 października 1801 roku, zachęcając zgromadzonych do podejmowania prac na rzecz dobra wspólnego, ostrzega przed publiczną kompromitacją. Jako przykład upadku autorytetu wskazuje losy Akademii Francuskiej:

[...] zgromadzenie to, mówię, zburzone, obalone, w gruzach swoich zakopane zostało; a to nie tylko bez upatrowania w tem jakiej straty, ale nawet z przyznaniem słuszności i poniekąd potrzeby. [Albertrandi 1802: 162]

Towarzystwo warszawskie powstaje zatem na gruzach świata, do którego należała również Akademia.

Pochwatę Józefa Szymanowskiego warto przeczytać w kontekście wydarzeń roku 1801, ze świadomością, że Towarzystwo dopiero szuka swojego przeznaczenia i próbuje różnych narracji o sobie samym. Autorzy wczesnych wystąpień często operują metakomentarzem do podejmowanych działań, czują się w obowiązku wytłumaczyć, co czynią, dlaczego i po co. Czy program Towarzystwa rysuje się wówczas zdecydowaną linią, czy wszyscy wypowiadający się członkowie są ze sobą zgodni co do pryncypiów?

8 W „Nowym Pamiętniku Warszawskim” drukowano cykl „Życia uczonych ludzi”.

9 Mercier opublikował Le Nouveau Paris w 1798 roku. 
W obszernej pochwale autorstwa Stanisława Kostki Potockiego z 9 maja roku 1801 (od strony pięćdziesiątej trzeciej do siedemdziesiątej trzeciej) zaledwie jedna trzecia objętości odnosi się do jej bohatera - Józefa Szymanowskiego, zmarłego 15 lutego tegoż roku. Dwie trzecie zajmuje opowieść, która pośrednio uzasadnia powołanie Towarzystwa Przyjaciół Nauk. Potocki sięga głęboko w przeszłość, do epoki, kiedy Rzym utracił swoją cywilizacyjną przewagę w świecie. Opowieść tę zreferuję, wspomagając się cytatami z omawianej pochwały. „Wygnane z Europy nauki i sztuki, dzikich barbarzyńców napływem [...] znalazły schronienie w Konstantyna stolicy" [Potocki 1802: 45]. Tam, choć skażone, zdziecinniałe, przetrwały aż do zdobycia Konstantynopola przez następców Mahometa. Zdawało się, że nastąpi kres nauk i sztuk, zwycięstwom Turków towarzyszyła sroga niechęć do cywilizacji zastanej. „Niczem była w oczach uczniów Mahometa, mądrość wieków i ludzi przy tej, którą w Koranie widzieli” [Potocki 1802: 45]. Sfanatyzowany „naród zwycięski” tępił nienawistne nauki, upatrując w nich przyczynę słabości zwyciężonych. „Tak przesądnego mniemania stały się ofiarą odwieczne składy rozumu i znajomości ludzkich" [Potocki 1802: 46]. Gdzie niegdyś kwitła wysoka cywilizacja, zapanowało jej przeciwieństwo: „[...] część świata niegdyś najoświeceńszą okrył fanatyzm najgrubszą niewiadomością, i na niej wzniósł tron ucisku i przemocy" [Potocki 1802: 46].

Upadek Konstantynopola sprawił jednak, że nauka i sztuka odrodziły się w Italii. Odrodziły się i rozkwitły na skalę nieznaną starożytnym Grekom i Rzymianom.

Wygnane z Carogrodu, wróciły do dawnego siedliska, i wnet Włochy stały się ich stolicą. Gotował wiek ten znakomite Europie zmiany, bujny w wielkich ludzi i w wielkie zdarzenia. Zewsząd niepospolite jakieś wzruszenie uczuć się dawało, i wróżyło nowy rzeczy porządek. Już zbiegli z Carogrodu mędrcy i artyści, znaleźli takie zawiązki nauki i sztuk w Europie, że tym nowym posiłkiem wzmocnione i popchnięte, wnet doszły stopnia doskonałości nieznanego Carogrodowi. [Potocki 1802: 46] 
Potocki [1802: 47] zatrzymuje się przy wynalazku prochu, który zmienia „gwałtu i śmierci prawidła”, unieważnia znaczenie „siły osobistej” walczących. Przemawia do niego argument, że proch jest narzędziem postępu.

Krwawsza na pozór, niż w rzeczy ta zmiana, zmniejszyła rzeź w bojach, a zapewniając narodom wypolerowanym wyższość wojenną nad barbarzyńskiemi, niegdyś Rzymu i świata burzycielami; pod hukiem armat, pod hasłem śmierci, życie trwałe nadała sztukom, naukom i swobodom naszym. [Potocki 1802:47]

Upowszechnienie druku ma skutek analogiczny. Dzięki niemu nauki rozkrzewiają się po świecie, a ich dorobek staje się niezniszczalny: „[...] czyniąc ich zagubienie niepodobnem, wyrwał je zapędom szalonych ludzi, wyrwał mocy wszystko niszczącego czasu, stał się ich wiecznym składem" [Potocki 1802: 47]. Odkrycia geograficzne zmieniają postać świata, ustanawiają nowe drogi handlowe i cyrkulację bogactwa. W odrodzeniu nauk i sztuk uczestniczą Polacy. Podróże do Włoch stają się zwyczajem elit.

Polska była jednym z najpierwszych krajów, w którym kwitły umiejętności po swoim powrocie do Europy. Co tylko Włochy w naukach i sztukach najdoskonalszego miały, to zdobiło dwór Zygmunta, to napełniało domy możnych podówczas Polaków, to narodowi za wzór, wszędy naśladowany, wystawianym było. [Potocki 1802: 49]

Ale i w Polsce, jak dawniej w Europie, przychodzi czas upadku. Po czym znowu nauka i sztuka pną się na wyższy poziom. Potocki przypomina, że to drugie odrodzenie wzięło początek w miejscu, gdzie aktualnie odbywa się posiedzenie Towarzystwa:

Z chwałą miejsca, z którego mówię, wspomnieć winienem, że $\mathrm{z}$ tego Zgromadzenia, z tych murów dane było hasło powrotu dobrego smaku nauk. Tkwi to w świeżej pamięci, jak śmiałą ręką Stanisław Konarski wstrząsnął pierwszy panujące w Pol- 
sce przesądy, co do stylu, co do nauk, co do sposobu nawet myślenia. [Potocki 1802: 50 ${ }^{10}$

Współtwórcą tego powrotu oświecenia, zakłóconego zmianami politycznymi, był też bohater pochwały - Szymanowski.

Jakie są główne filary znaczeniowe opowieści, w którą Potocki wplótł losy Szymanowskiego? W skali makroświatowej przez wieki toczy się gra o postępy oświaty. W minionym czasie oświecenie nie postępowało w sposób ciągły i sukcesywny. Zdarzały się załamania, epoki regresu, w których prawie cały dorobek nauk i sztuk obracano w niwecz. Cywilizacja jest $\mathrm{w}$ tej opowieści porządkiem kruchym i odwracalnym. Pocieszające jest to, że tam, gdzie oświecenie osiągnęło wysoki poziom, regres może zostać przełamany. Takie wnioski płyną z dziejów Italii. Podobną sinusoidę kulturowych wlotów i upadków można zaobserwować również w historii Polski. Skoro zatem Polska miała swój złoty wiek, jest nadzieja, że $\mathrm{z}$ upadku jeszcze się podźwignie.

Można odnieść wrażenie, że uczczenie zmarłego Szymanowskiego stworzyło Potockiemu jedynie pretekst, by przedstawić opowieść o dziejach światowego oświecenia i umiejscowieniu w nich Polski. Zwłaszcza że opowieścią powyższą zdawał się konkurować z prezesem Towarzystwa, Janem Chrzcicielem Albertrandim, który podobnie rozległą perspektywę czasową i przestrzenną uruchomił w swojej przemowie na pierwszym posiedzeniu 23 listopada 1800 roku. Albertrandi również miał na względzie dzieje oświecenia, ale w jego opowieści akcenty rozłożyły się inaczej.

Mówca traktuje podbój jako zjawisko pospolite w historii. Rozróżnia przy tym dwa rodzaje zaborców. Pierwsi niszczą cywilizację, którą zastają na terytorium podbitym. Drudzy cenią ludzkie osiągnięcia niezależnie od ich proweniencji. W przeszłości zdarzały się narody zdobywców

tak w dzikości swojej nieugłaskane, tak w zawziętości niepowścignione, tak w uprzedzonych zdaniach swoich zacięte, iż nie tylko zdobytych i pod jarzmo swoje paddanych krain 
prawa, rządy, imię wytępić usiłowały; ale nawet większą przeciw naukom niż przeciw ludziom wywierając zawziętość, ciemnością, których same okryte byly grubą oponą, ogarnąć usiłowały tych, co zmiennej fortuny losem, pierwotnego stanu i udzielnych zaszczytów byli pozbawieni. [Albertrandi 1802: 4]

Historia zna niemało przykładów takich barbarzyńskich podbojów:

Kto albowiem nie wie, jaką na część wielką Europy noc rozpostarly grube owe chmury Hunnów, Alanów, Awarów, Herulów, Turcilingów? Kto nie widzi, jak zapęziałemi stały się i nikczemnemi, wspaniałe one i bystre Greków dowcipy, pod Ottomanów dziką nauk prawie wszystkich nienawiścią? Kto nie słyszał, co rozjadła zagorzałość Omara, lub Leona Isauryka nieskrowita zawziętość, nauki w ohydzie mająca sprawiła? [Albertrandi 1802: 4]

Albertrandi przypomniał spalenie słynnych bibliotek: w Aleksandrii i Konstantynopolu. Zagładę nauk spowodowali również Tatarzy: „Komu nie są wiadome okropne skutki wypadłej z azjatyckich jaskiń szarańczy onej tatarskiej, która w trzynastym wieku, w tylu krajach z szczątkiem wszystkie nauk latorośle pożarła?” [Albertrandi 1802: 4].

Rozebrana Polska - objaśniał prezes historię ostatnich lat miała to szczęście, że znalazła się pod panowaniem mocarstw oświeconych, które „cenią nauki, kochają umiejętności, rozciągają do nich dzielną opiekę swoję" [Albertrandi 1802: 4]. Mówca żywił nadzieję, że protekcja rządowa obejmie wszelkie dziedziny nauk, łącznie z uprawianymi przez polskich poddanych. Podkreślał dysproporcję możliwości między państwem pruskim a Polakami.

Nic to nie znaczy - przekonywał zgromadzonych - że pochodnią jednę trzyma olbrzym ogromny, cały żelazem okryty, drugą zaś w wzroście upośledzony, słaby, a może i spętany; jeśli równe są pochodnie, jeśli równo rozpalone, jedna nie 
mniej jak druga, na wszystkie strony najżywsze światło rozrzuca. [Albertrandi 1802: 17]

Oświecenie, jego zdaniem, nie miało barwy narodowej:

Jakoż wszyscy, z prawdziwą i wytrwałą gorliwością do zachowania i pomnożenia nauk pożytecznych przykładający się, wszyscy ubiegający się do prawdziwej i gruntownej umiejętności, członkami są jednego narodu, po całym świecie rozlegającego się; mało powiedziałem, członkami są jednej familii różne siedliska mającej, najściślejszym związkiem skojarzonej, jeden cel, jeden zamiar, jedne pragnienia, jednę dzielnicę i nierozdzielną własność mającej. Czarny, śniady, biały, oliwkowy, miedziasty, wszyscy jednej postaci są i fizjonomii, jedność familii i pobratymstwo okazującej. [Albertrandi 1802: 17]

Albertrandi wyznawał publicznie, że człowiek oświecony identyfikuje się z całym światem. Ceni wszystkie kultury, potrafi oszacować ich zdobycze, nie żywi uprzedzeń wobec kulturowej odmienności.

Co Chińczyk z ksiąg Konfucjusza wykłada; co Bramin w Wedamie, lub Shaterze czyta; co Akademicy w Benares roztrząsają; co Guebr w Zoroastra księgach thumaczy; co Meksykan lub Peruwianin na sznurkach swoich węzełkami wyraził; co Islandczyk w sagach swoich, Got w runach opiewa; co bardowie śpiewali, druidowie opowiadali, skaldowie potomnym wiekom podawali, co Kozacy w dumach rodakom swoim nucili, wszystko to do wszystkich tej familii członków, i do każdego z nich w szczególności należy. [Albertrandi 1802: 19]

Ludzie nauki, podkreślał, nie znają ograniczeń, ani przestrzennych, ani czasowych:

Przedziały jeograficzne, polityczne, moralne, narody jedne od drugich rozłączające, do tych, co się naukami zaprzątają, póki z tego szeregu nie występują, cale nie należą. Alpy, Pirenej, Tatry, Taurus i Kaukaz, przed niemi osiadają; osychają 
bezdenne Oceany, klimatów i zon różność ustaje; niknie przetworność odległości, pogranicznemi stają się Antypody; niknie i przeciągłość wieków, a starożytność najodleglejsza staje się spółczesną. [Albertrandi 1802: 4]

Z punktu widzenia uczonego świat stał otworem. Albertrandi wciąż od nowa podejmował wątek różnic, które separują od siebie narody, ale dla ludzi nauki nie stanowią przeszkody w porozumieniu. „Choć języki są odmienne” - zaczynał serię elementów różnicujących, po czym konkludował, opisując relację między uczonymi a rządem:

[...] wszyscy jednak jedno ciało, w rozterkach zgodne, w rozproszeniu spojone, w różności widoków, zamiarów, jednostajność zachowujące składają; któremu w tym składzie rząd polityczny rzeczą jest obcą, od troskliwości onego odsunioną, czci tylko i podległości wyciągającą, tak dalece, iż w to ciało wchodzący żądać mogą, aby filozofia na tronie osiadła, ale nigdy nie pragną, aby filozofowie rządem kierowali; jednakże w stanie obywatelskim, uczony każdy do swej stąd wynikającej zna się powinności, poprzedzającem nawet prawa, rozumu przekonaniem. [Albertrandi 1802: 4]

Mówca nie pozostawiał cienia wątpliwości, że uczonymi nie targają ambicje polityczne, co więcej, że nie trzyma ich w ryzach obawa przed karą, lecz racje rozumowe.

Albertrandi prowadził swoją rzecz w taki sposób, że po pierwsze ludzi nauki wyzwalał z wszelkich możliwych więzów i ograniczeń, a po drugie nie czynił ,autokracji” warunkiem rozwoju nauk i sztuk. Współczesną Italię przedstawiał jako kraj pod obcym panowaniem, przechodzący z rąk do rąk, a mimo to kwitnący kulturowo. Niepokoje polityczne nie zlikwidowały tam zapału do nauk, szkolnictwo miało się dobrze, Włosi gromadzili księgozbiory, skupiali się w towarzystwach uczonych.

Mimo kilku punktów wspólnych, opowieści Albertrandiego i Potockiego nie da się ze sobą uzgodnić. Pierwszy z nich przekonuje, że nauka i sztuka mogą zachować autonomię w stosunku 
do polityki. Wymaga to jednak oświeconego rządu. Z kolei w Pochwale... autorstwa Potockiego obie te dziedziny ściśle się ze sobą wiążą: oświecenie doznaje wstrząsów na skutek zawirowań politycznych albo też kryzys kultury narodowej sprowadza agresję z zewnątrz.

Pozostaje zastanowić się jeszcze nad relacją opowieści o dziejach oświecenia do biografii Szymanowskiego. W kontekście tej wielkiej opowieści tłumaczy się wysoka ocena Światyni Wenery $z$ Knidos. Potocki bowiem potrzebował tekstowego potwierdzenia, że język polski, przedstawiany tu jako język słowiański, osiągnął już stan pełnej dojrzałości, co pomnażało jego szanse na przetrwanie. Stawką w grze po katastrofie państwa jest bowiem powstrzymanie kulturowego i cywilizacyjnego regresu pod obcą władzą.

Na uwagę zasługuje jeszcze jeden wątek Pochwaty... - przewlekła choroba jej bohatera. Mecherzyński pisał, że autorzy pochwalnych biografii ludzi uczonych mieli z nimi kłopot, bo w życiu uczonego zwykle niewiele się dzieje. Z braku spektakularnych zdarzeń musieli nadrabiać figurami stylu. Trudność Potockiego jako biografa polegała na tym, że Szymanowski nie dość, że był człowiekiem pióra, to jeszcze całymi latami chorował, przez co nie w pełni mógł uczestniczyć w historycznych wydarzeniach, nie zdecydował się na założenie rodziny. Potocki nie tylko nie pominął milczeniem przypadłości bohatera Pochwały..., lecz przydał jej znaczenia symbolicznego - retorycznie ją „powiększył”. Psychofizyczny stan Szymanowskiego połączył ze stanem ojczyzny. „Miało wpływ nad zdrowiem Szymanowskiego, zdrowie ojczyzny, które zdrowiem jego nazwać można było, odtąd jak swoje utracił” [Potocki 1802: 68]. Nadzieje epoki „Sejmu Konstytucyjnego” pobudziły jego siły żywotne. Zanim więc Mickiewicz napisał o ojczyźnie, która jest jak zdrowie, ubiegł go Potocki w Pochwale... z 1801 roku. Łącząc tak ściśle jestestwo poszczególne z ciałem zbiorowym jak najdalszy był natomiast autor biografii pochwalnej Szymanowskiego od wyobrażeń Albertrandiego, który chciał widzieć uczonych jako obywateli świata. Przy czym różnica między nimi nie wynikała stąd wyłącznie, że inaczej patrzyli na świat, że punkt widzenia polskiego arystokraty różnił się od punktu widzenia 
człowieka "nauki i talentu”", duchownego, syna włoskiego imigranta, lecz miała źródło w gwałtownych przemianach, jakim ulegała rzeczywistość polityczno-społeczna na początku XIX wieku. Wszak między pierwszym a drugim posiedzeniem warszawskiego Towarzystwa Przyjaciół Nauk zaczęło się w Rosji panowanie Aleksandra I, w niedalekiej przyszłości kluczowego rywala Napoleona $\mathrm{w}$ grze o panowanie nad kontynentem euroazjatyckim. Ziemie polskie jako pomost między Wschodem a Zachodem znajdowały się w centralnym punkcie tej rywalizacji.

\section{Bibliografia}

Albertrandi Jan Chrzciciel (1802), Mowa na pierwszym posiedzeniu Towarzystwa Warszawskiego Przyjaciół Nauk, „Roczniki

Towarzystwa Warszawskiego Przyjaciół Nauk”, t. 1, s. 1-25. Bartoszewicz Julian (1877), Historia literatury polskiej potocznym sposobem opowiedziana, t. 2, wyd. 2 powiększone, nakładem Kazimierza Bartoszewicza, drukiem W. Korneckiego, Kraków. Burke Peter (2011), Fabrykacja Ludwika XIV, przeł. Robert Pucek, Michał Szczubiałka, Wydawnictwo Uniwersytetu Warszawskiego, Warszawa.

Curtius Ernst Robert (1997), Literatura europejska i łacińskie średniowiecze, przeł. i oprac. Andrzej Borowski, Universitas, Kraków.

Czepulis-Rastenis Ryszarda (1988), Ludzie nauki i talentu. Studia o świadomości społecznej inteligencji polskiej w zaborze rosyjskim, PIW, Warszawa.

Dmochowski Franciszek Salezy (1829), Odpowiedź na pismo p. Mickiewicza o krytykach i recenzentach warszawskich obejmująca tekst p. Mickiewicz z uwagami krytycznemi, Drukarnia Gazety Korespondenta, Warszawa.

Dmochowski Franciszek Salezy (1959), Wspomnienia od 1806 do 1830 roku, oprac. i wstęp Zdzisław Libera, PIw, Warszawa.

Dziechcińska Hanna (1970), Żywot Jana Tarnowskiego, pióra Stanisława Orzechowskiego, staropolska biografia pochwalna, „Odrodzenie i Reformacja w Polsce”, t. 15, s. 67-87.

Dziechcińska Hanna (1971), Biografistyka staropolska w latach 1476-1627. Kierunki i odmiany, Ossolineum, Wrocław. 
„Gazeta Warszawska” (1801), nr 38.

Jurkowska Hanna (2014), Pamięć sentymentalna. Praktyki pamięci w kręgu Towarzystwa Warszawskiego Przyjaciót Nauk, Wydawnictwo Uniwersytetu Warszawskiego, Warszawa.

Kraushar Aleksander (1900), Towarzystwo Warszawskie Przyjaciót Nauk 1800-1832, t. 1, Gebethner i Wolf, Kraków-Warszawa.

Maciejowski Wacław Aleksander (1852), Piśmiennictwo polskie od czasów najdawniejszych aż do roku 183o, t. 2, nakładem i drukiem Samuela Orgelbranda, Warszawa.

Mecherzyński Karol (1860), Historia wymowy w Polsce, t. 3, nakładem Józefa Czecha, Kraków.

Mickiewicz Adam (1829), Poezje, t. 1, Petersburg.

Obremski Krzysztof (2003), Panegiryczna sztuka postaciowania: August II Mocny (J.K. Rubinkowski, „Promienie cnót królewskich”...), Wydawnictwo UMK, Toruń.

Odezwa Towarzystwa Warszawskiego Przyjaciół Nauk, z doniesieniem o reskrypcie J.K. Mci zatwierdzajacem toż Towarzystwo (1802), „Roczniki Towarzystwa Warszawskiego Przyjaciół Nauk”, t. 1, s. v-X.

Potocki Stanisław Kostka (1802), Pochwała Józefa Szymanowskiego, „Roczniki Towarzystwa Warszawskiego Przyjaciół Nauk”, t. 1, s. 53-73.

Skarbek Fryderyk (1860), Wspomnienie o Warszawskim Towarzystwie Przyjaciół Nauk, drukarnia C.K. Uniwersytetu Jagiellońskiego, Kraków.

Smoleński Władysław (1949), Przewrót umysłowy w Polsce wieku XVIII, PIw, Warszawa.

Wójcicki Kazimierz Władysław (1845), Historia literatury polskiej w zarysach, t. 2, nakładem Gustawa Sennewalda, drukarnia J. Ungera, Warszawa.

\section{Elżbieta Dąbrowicz}

\section{Laudatory biography from May 9, 1801. A Contextual Interpretation}

Comprehensive work on the history of nineteenth-century biographical texts has not been written yet and if it had, it would have to include the laudatory biographies practiced by Warsaw's Towarzystwo Przyjaciól Nauk (Society of Friends of Arts and Sciences). An extensive collection of them can be found in their yearbooks.

This article's object of interest is Pochwała Józefa Szymanowskiego [Praise of Józef Szymanowski] by Stanisław Kostka Potocki, which was oftentimes cited as an example of exorbitant rhetoric in the past. Widely commented unearned praise of the translation of Światynia Wenery 
$w$ Knidos [Venus temple in Knidos] casts shadow on TPN's entire biographical work. The critics of the aforementioned Pochwata Józefa Szymanowskiego completely overlooked a substantial part of it which could be recognized as the founding story of the organization conceived in the Prussian part of the partitioned Poland; one that was taking its first shaky steps in uncertain times when the situation in Europe and the rest of the world was changing on a daily basis.

Keywords: praise; Stanisław Kostka Potocki; Józef Szymanowski; Towarzystwo Przyjaciół Nauk.

Elżbieta Dąbrowicz - historyk literatury XIX i XX wieku; zajmuje się literaturą polską w perspektywie życia publicznego, zróżnicowaniem regionalnym piśmiennictwa na ziemiach polskich, epistolografią i biografistyką. Jest autorką książek: Cyprian Norwid. Osoby i listy (1997), Galeria ojców. Autorytet publiczny w literaturze polskiej lat 1800-1861 (2009), Cenzura na gruzach. Szkice o literackich świadectwach życia w PRL-u (2017), Romantyzm ziemi przechodów. Próby terytorialnej historii literatury (2019). 
